\title{
Practical Research on "Sharing" Activities in College English Teaching
}

\author{
Xiangfa Zeng ${ }^{1, ~ a}$, Jing $\mathrm{Ke}^{2, \mathrm{~b} \text {,* }}$ \\ ${ }^{1}$ Chengdu Medical College, Chengdu, Sichuan, China \\ ${ }^{2 *}$ Corresponding Author, Chengdu Medical College, Chengdu, Sichuan, China \\ a1362806408@qq.comb.1120871808@qq.com \\ *corresponding author
}

Keywords: Sharing; English learning anxiety; self-confidence; optimism

\begin{abstract}
Objective: To discuss the effects on the cultivation of college students' humanistic qualities and English language abilities of "sharing" teaching activities applied in college English teaching. Methods: In routine college English teaching, the good news and events with positive energy in students' life are shared before textbook study. After one year of teaching practice, a questionnaire survey was conducted on college students, and SPSS 21.0 statistical software package was used for data analysis. Results: The statistical analysis showed that the scores of college students' acceptance of "sharing" teaching activities were $4.13 \pm 0.865$. The students thought that the score for improving their oral English ability was $4.27 \pm 0.866$, the score of listening comprehension ability was $4.53 \pm 0.630$, the score for improving English learning interest was $4.48 \pm 0.604$, the score for reducing English learning anxiety was $4.48 \pm 0.681$, while self-confidence score was $4.35 \pm 0.663$, self-optimism score was $4.44 \pm 0.602$, and self-help qualities scored $4.28 \pm 0728$. Conclusion: The statistical results reflect that most college students like "sharing" teaching activities and believe that it can greatly improve college students' interest in English learning, improve their oral English and their English listening ability, reduce their learning anxiety in the English classroom, and cultivate their positive and optimistic attitude towards life and the quality of mutual support, so that students become more confident.
\end{abstract}

\section{Introduction}

Higher education institutions are the cradle for cultivating high-quality talents needed for national construction. The college students of the 21st century are the pillars of national construction. They shoulder heavy responsibilities and need to be developed in morality, intelligence, physical, art and labor. They need to be of a sound personality and good psychological quality with high ideological and political qualities and corresponding scientific and cultural qualities. Therefore, colleges and universities must give top priority to the cultivation of student quality. The basic qualities of college students include moral qualities, cultural qualities, professional qualities, physical and mental qualities, of which cultural quality is the foundation. To strengthen cultural quality education, the focus is on the humanities quality education. "Humanities 
quality" refers to the humanistic knowledge possessed by human beings and the personality, temperament and self-cultivation demonstrated in the human body after the internalization of such knowledge (Xiaoping Tan, Jinxiu Jing 2011). At present, the values of college students are not optimistic. In the value of life, some college students worship money, attach importance to material possession but disregard dedication, attach importance to money but disregard morality, and pursue a comfortable life. The education of college students' values needs to be strengthened (Yan Chen 2015). In the market economy system, students' views on money are an important manifestation of values. The pursuit and inspiration of the spirit is not enough, the ideological realm is not enough, and the education of students' outlook on life and values needs to be strengthened (Yamei Li, Lina Yao, Jin Hong 2007). As an important education method for humanistic literacy education, college English course plays an important role in cultivating the values and humanistic qualities of college students in addition to the "two courses" education, class activities, and party lectures. "College English courses have practical significance and long-term impact on the future development of college students. Learning English helps students establish a global vision, foster international awareness, and improve humanistic qualities while providing a basic tool for new knowledge, potential development and comprehensive development, making students well prepared to meet the challenges and opportunities of the globalized era." (Outline of National Medium and Long-Term Program for Education Reform and Development (2010-2020)).

In order to improve students' humanistic qualities, we refer to Unit 2 in "New Century College English (Version 2): An Integrated English Course (2)" according to College English teaching content. Before textbook learning, students were required to share good events, news, message in daily learning and life, such as: 1 .Who has good news? 2.Who has something good to say? 3.The thing/person I am thankful for. 4. I want to say something complimentary about my classmate(s). 5. The funny thing(s) I want to share. About 10 minutes of sharing each time, the entire sharing activities lasted for a school year and students actively participated in the sharing activities.

\section{Objects and Methods}

The subjects of the research were students from Class 2, Class 4, and Class 6 of the 2017 medical laboratory technology the author taught. During the one-year college English teaching activities, students were free to share happy events, news and message in daily learning and life before textbook teaching. Each time the activity lasted about 10 minutes. Students' sharing performance was recorded as part of their daily performance scores. After one year of teaching practice, "sharing" teaching activities were investigated. The questionnaire was modified from the questionnaire Zhangyan Miao designed. A total of 8 questions in the questionnaire were applied to investigate students' attitudes towards "sharing" teaching activities. This activity has the role in improving students' oral English, listening comprehension, and interest in English learning, reducing students' English learning anxiety, and cultivating students' quality of helping and caring each other, promoting self-confidence, positive and optimistic humanistic qualities. Each question used Linker five-grade scale. Five responses are "strongly agree”, "agree", "not necessarily", “disagree", and "strongly disagree". They are recorded respectively 5, 4, 3, 2, 1 point. A total of 128 questionnaires were issued and 124 valid questionnaires were recovered. The recovery rate was $6.88 \%$. 


\section{Results}

\subsection{College students"' acceptance of "sharing" teaching activities}

The degree of recognition of "sharing" teaching activities among college students is shown in Table 1. Judging from the statistical results, students agree with the "sharing" teaching activities, scoring $4.13 \pm 0.865$. They like to share their happiness in life with their classmates.

Table 1 Statistical table of college students' acceptance of "sharing” teaching activities

\begin{tabular}{cccccc}
\hline Category & $\begin{array}{c}\text { Question } \\
\text { Item }\end{array}$ & $\begin{array}{c}\text { The Lowest } \\
\text { Point }\end{array}$ & $\begin{array}{c}\text { The Highest } \\
\text { Point }\end{array}$ & Mean & $\begin{array}{c}\text { The Standard } \\
\text { Deviation }\end{array}$ \\
\hline $\begin{array}{c}\text { Teaching } \\
\begin{array}{c}\text { Activity } \\
\text { Recognition }\end{array}\end{array}$ & 1 & 1 & 5 & 4.13 & 0.865 \\
\hline
\end{tabular}

\subsection{The effect of "sharing" teaching activities on improving college students' oral English and listening ability}

College English teaching aims at developing students' listening, speaking, reading, writing and translation abilities. The effect on "sharing" teaching activities in improving oral English and listening ability of college students is shown in Table 2. The statistical results show that college students believe that "sharing" teaching activities can greatly improve their English speaking and listening skills, scoring $4.27 \pm 0.866$ and $4.53 \pm 0.630$, respectively. They believe that this activity increases the opportunities for them to practice speaking and listening.

Table 2 Statistics of the roles of "sharing” teaching activities in improving students' spoken and listening ability

\begin{tabular}{cccccc}
\hline Category & $\begin{array}{c}\text { Question } \\
\text { Item }\end{array}$ & $\begin{array}{c}\text { The } \\
\text { Lowest Point }\end{array}$ & $\begin{array}{c}\text { The } \\
\text { Highest Point }\end{array}$ & Mean & $\begin{array}{c}\text { The Standard } \\
\text { Deviation }\end{array}$ \\
\hline Spoken English & 2 & 1 & 5 & 4.27 & 0.866 \\
\hline $\begin{array}{c}\text { Listening } \\
\text { comprehension }\end{array}$ & 6 & 3 & 5 & 4.53 & 0.630 \\
\hline
\end{tabular}

3.3. The role of "sharing" teaching activities in cultivating college students' self-confidence, optimism and helping others

The role of "sharing" teaching activities in cultivating college students' confidence, optimism and interest in learning English is shown in Table 3. The statistical results show that college students believe that "sharing" teaching activities can greatly improve their self-confidence, develop positive and optimistic attitudes to life and the quality of helping, and improve their interest in English learning, scoring $4.35 \pm 0.663,4.44 \pm 0.602,4.28 \pm 0.728$ respectively, basically close to the "strongly agree" option. 
Table 3 The role of “sharing” teaching activities in cultivating students' confidence, optimism, and helping people

\begin{tabular}{cccccc}
\hline Category & $\begin{array}{c}\text { Question } \\
\text { Item }\end{array}$ & $\begin{array}{c}\text { The Lowest } \\
\text { Point }\end{array}$ & $\begin{array}{c}\text { The Highest } \\
\text { Point }\end{array}$ & Mean & $\begin{array}{c}\text { The Standard } \\
\text { Deviation }\end{array}$ \\
\hline Confidence & 4 & 2 & 5 & 4.35 & 0.663 \\
Optimism & 5 & 3 & 5 & 4.44 & 0.602 \\
\hline Helping & 3 & 2 & 5 & 4.28 & 0.728 \\
\hline
\end{tabular}

\subsection{The effect of sharing teaching activities on improving college students' interest in English} learning and reducing English learning anxiety

College students believe that "sharing" teaching activities can improve their interest in English learning, and accordingly reduce English learning anxiety. The statistical results are shown in Table 4. The statistical results in the table 4 reflect that "sharing" teaching activities can improve their English learning interests with a score of $4.53 \pm 0.630$. The score of "sharing" teaching activities to reduce English learning anxiety was $4.48+0.684$. The two statistical results support each other and confirm the role of "sharing" teaching activities in this area.

Table 4 Statistics of "sharing” teaching activities to improve students' interest in English learning and reduce English learning anxiety

\begin{tabular}{cccccc}
\hline Category & $\begin{array}{c}\text { Question } \\
\text { Item }\end{array}$ & $\begin{array}{c}\text { The } \\
\text { Lowest Point }\end{array}$ & $\begin{array}{c}\text { The } \\
\text { Highest Point }\end{array}$ & Mean & $\begin{array}{c}\text { The Standard } \\
\text { Deviation }\end{array}$ \\
\hline English Interest & 7 & 3 & 5 & 4.53 & 0.630 \\
\hline $\begin{array}{c}\text { English Learning } \\
\text { Anxiety }\end{array}$ & 8 & 2 & 5 & 4.48 & 0.681 \\
\hline
\end{tabular}

\section{Discussion}

As we can see from the statistics in Table 1, the "sharing" teaching activities have been fully recognized by college students (scoring $4.13 \pm 0.865$ ). While, Table 2, Table 3, and Table 4 reveal the reasons why the "sharing" teaching activities were fully approved by college students. Because the teaching activities not only improved the students' interest in English learning, oral English, English listening ability, but also reduced their anxiety in English learning (scoring 4.48 \pm 0.684 ). On the other hand, in the "sharing" teaching activities, students have the opportunity to practice oral English. They bring happiness to the students when sharing happiness. This can make students more confident and psychologically positive and optimistic, the quality of helping and caring each other is cultivated. The news and events shared by the students in the "sharing" teaching activities come from all aspects of life. For example, some student shared their gratitude to their roommates for looking after her when she was ill in hospital. Some student shared the benefits that the opening of the railway line Xi'an-Chengdu brings to his return home and the economic development of his hometown. Some student shared the opening of Chengdu Metro Line 10 and Line 3, which brought convenience to travel abroad and reduced the pollution to the environment caused by cars. Some student shared that the pediatrics specialty of our university was included into the 1st batch of enrollment for undergraduates, which brought opportunities for the development of pediatrics and the development of the entire college. Some student shared the news of the Panmunjom meeting between South Korean and North Korean leaders and the Sino-U.S. leaders' meeting in Singapore, which brought peace to East Asia and the world, and brought better strategic development to China. 
Some students shared the news that China learned lessons from the Sino-US trade war and increased investment in chip research to improve China's high-tech competitiveness. These materials come from life and are more familiar to students, so that the English language learning has a more vibrant material. Through sharing activities, students can learn to apply the language knowledge they learned to life, enrich language learning materials, improve students' ability to focus on and discover happy things in life, and also increase students' opportunities for language training, which will naturally train students' oral English and listening comprehension skills. At the same time, it also improves students' sense of accomplishment in language learning, thus reducing their anxiety in learning English and being more willing to devote their energies to English language learning. According to Second Language Acquisition Theory proposed by Chomsky and Krashen, language is not obtained by "learning”. As long as the language input has enough positive evidence, every normal person can acquire the language. The continuous process of language acquisition is the process of improving students' comprehensive language using ability. While, the "sharing" teaching activities before college English classes provide valuable opportunities for students' language acquisition. In the sharing process, the students not only trained their English language comprehensive ability, but also gained a sense of achievement, reduced the anxiety of English language learning, and this provided the impetus for other language learning activities.

From the perspective of the cultivation of students' humanistic qualities, to be positive and optimistic, helpful, kind and self-confident are very vital to the growth and success of a college student. Through "sharing" teaching activities, students are more concerned with positive events, and message in their daily learning life, and students are guided to discover good things in life and learn to be grateful to others and willing to share joy in life. Students learn to change from "exclusive" to "share" and develop it. "Sharing your happiness is much better than enjoying your happiness by your own(king Hui of Liang)”. Finding resonance and sharing is a responsibility for society. Educators bear the important task of teaching and educating people. As one of the university's workers, College English teachers also undertake the mission of teaching, managing, serving and educating people, so as to help students form healthy psychology.

The atmosphere of being eager for quick success and instant benefits and impatience on university campuses is increasingly prevalent, and education and teaching are difficult to become real excitement points. As the result, the already fragile humanistic atmosphere of colleges and universities is gradually obscured by utilitarian thinking, so that the cultural quality of some college students is not only congenitally deficient, but also absent from acquired education. The nine-year compulsory education based on exam-oriented education gives them a relatively lack of cultural knowledge, resulting in the congenital deficiency of the humanistic quality of college students. Colleges and universities, as the "highland" of cultivating talents, shoulder the lofty historical mission. Training high-quality and first-rate talents is the ultimate goal of higher education (Juan Tian 2006). Colleges and universities should integrate the humanistic spirit and humanistic knowledge into the students' activities. Students should be able to deeply feel the nourishment of the humanistic spirit in a pleasant activity experience, and experience the profoundness of the humanistic knowledge so as to increase the interest in learning and actively promote the humanistic quality. College English course can combine the cultivation of language proficiency with the cultivation of students' humanistic literacy (Chanjuan Xu 2017).

On the other hand, in the "sharing" teaching activities, due to past study habits, some students need to further strengthen their enthusiasm for "sharing". Students' oral and listening skills also need to be strengthened. 


\section{Conclusion}

Through one year practice of "sharing" activities before class teaching in College English and the analysis of students' questionnaire, it is found that college students have a higher acceptance of "sharing" teaching activities. They believe that this teaching activity can improve their oral expression ability, listening comprehension ability, interest in English learning, and reduce English learning anxiety in English learning. At the same time, they can cultivate their life attitude of positive, optimistic and confident and the quality of helping and caring each other, which helps to cultivate high-quality college students. As an important course for the cultivation of humanistic literacy, College English course can organically combine the cultivation of English language comprehensive ability with the cultivation of students' humanistic literacy and exert its unique educational function.

\section{Acknowledgement}

The research is financially supported by Sichuan Provincial Foreign Language Literature Research Center (Grant NO: SCWYH18-04)

\section{References}

[1] Zangli Bian, KaibinWang. Analysis and Thinking on the status quo of medical students' Quality Education[J]. Health Vocational Education,2006(19):142-144.

[2] Yan Chen. The Status Quo of Students' Qualities in Local Colleges and Its Cultivation Strategy[J]. Journal of Xiangyang Polytechnic Vocational Institute ,2015,14(01):114-116.

[3] Yamei Li, Lina Yao, Jin Hong. The Investigation and Analysis of Medical Students' Humanities Quality[J]. Medicine and Philosophy(Humanistic and Social Medicine Edition),2007(05):43-44.

[4] Xiubai Qin, Huaijian Zhang. "New Century College English (Version 2):An Integrated English Course(2)”[M]. Shanghai: Shanghai Foreign Language Education Press 2014.03:38-41

[5] Xiaoping Tan. Investigation and analysis of the present situation of College Students' Humanistic Quality[J].Time Education: Education and teaching,2011,(5):6-7.

[6] Juan Tian. Analysis and Countermeasures of quality education for college students in China[J]. Journal of Chengdu Technological University,2006(03):52-54+42.

[7] Chanjuan Xu. Study and Countermeasures on the Status Quo of the "Post-95" Medical Students' Humanities Quality in Local Colleges[J].The modern vocational education,2017,0(13):84-85.

[8] Yucai Zheng. Investigation and Analysis on the status quo of College Students' quality[J]. Social Science Forum,2005(05):68-70.

[9] China Legal Publishing House. Outline of National Medium and Long-Term Program for Education Reform and Development (2010-2020)[M]. Beijing:China Legal Publishing House.2010.08

[10] Wenhua Zhu.The Basic Approaches of Quality Education for Senior Medical Talents in the 21st Century[J].Journal of Qingdao University Medical College,2001(03):246-248. 